\title{
Selective Stimulation of VEGFR2 Accelerates Progressive Renal Disease
}

\author{
Waichi Sato, ${ }^{*}$ Katsuyuki Tanabe, ${ }^{\dagger}$ \\ Tomoki Kosugi, ${ }^{\dagger}$ Kelly Hudkins, ${ }^{\ddagger}$ \\ Miguel A. Lanaspa, ${ }^{*}$ Li Zhang, ${ }^{\S}$ \\ Martha Campbell-Thompson, ${ }^{\$}$ Qiuhong Li, \\ David A. Long," Charles E. Alpers, ${ }^{\ddagger}$ and \\ Takahiko Nakagawa*† \\ From the Division of Nephrology, the Molecular Pathology and \\ Immunology Core Laboratory, ${ }^{\S}$ and the Department of \\ Ophthalmology, "University of Florida, Gainesville, Florida; the \\ Division of Renal Disease and Hypertension, ${ }^{\dagger}$ University of \\ Colorado, Denver, Aurora, Colorado; the Department of \\ Pathology, ${ }^{\ddagger}$ University of Washington, Seattle, Washington; and \\ the Nephro-Urology Unit," University College London Institute of \\ Child Health, University College London, London, United \\ Kingdom
}

Vascular endothelial growth factor A (VEGF-A) can play both beneficial and deleterious roles in renal diseases, where its specific function might be determined by nitric oxide bioavailability. The complexity of VEGF-A in renal disease could in part be accounted for by the distinct roles of its two receptors; VEGFR1 is involved in the inflammatory responses, whereas VEGFR2 predominantly mediates angiogenesis. Because nondiabetic chronic renal disease is associated with capillary loss, we hypothesized that selective stimulation of VEGFR 2 could be beneficial in this setting. However, VEGFR2 activation may be deleterious in the presence of nitric oxide deficiency. We systematically overexpressed a mutant form of VEGF-A binding only VEGFR2 (Flk-sel) using an adeno-associated virus-1 vector in wild-type and eNOS knockout mice and then induced renal injury by uninephrectomy. Flksel treatment increased angiogenesis and lowered blood pressure in both mouse types. Flk-sel overexpression caused mesangial injury with increased proliferation associated with elevated expression of PDGF, PDGF- $\beta$ receptor, and VEGFR2; this effect was greater in eNOS knockout than in wild-type mice. Flk-sel also induced tubulointerstitial injury, with some tubular epithelial cells expressing $\alpha$-smooth muscle actin, indicating a phenotypic evolution toward myofibroblasts. In conclusion, prestimulation of VEGFR2 can potentiate subse- quent renal injury in mice, an effect enhanced in the setting of nitric oxide deficiency. (Am J Patbol 2011, 179: 155-166; DOI: 10.1016/j.ajpath.2011.03.024)

Vascular endothelial growth factor A (VEGF-A) plays a key role in maintaining peritubular and glomerular capillary integrity in the normal kidney. In renal disease, however, the actions of VEGF-A are more complicated. A reduction in renal VEGF-A is observed in acute and chronic nondiabetic renal disease, mostly associated with a loss of glomerular and peritubular capillaries. ${ }^{1-5}$ In these situations, administration of VEGF-A has been shown to improve renal histology and function. $3,4,6,7$ In contrast, levels of both circulating and local VEGF-A are high in diabetes, and excessive VEGF-A has been shown to have a role in mediating glomerular hypertrophy, proteinuria, and retinopathy, ${ }^{8,9}$ indicating that VEGF-A is deleterious in this unique situation. Given the fact that diabetic conditions are associated with a lower bioavailability of nitric oxide (NO), we have proposed a hypothesis that the deleterious effect of VEGF-A in diabetes could be attributed to a reduced bioavailability of endothelial NO in the kidney. Consistent with this hypothesis, diabetic nephropathy is worsened in the setting of endothelial NO deficiency and the effects of VEGF-A to induce angiogenesis and inflammation are enhanced in this setting. ${ }^{10,11}$

The actions of VEGF-A are mediated through its two receptors, Flt-1 (VEGFR1) and Flk-1 (VEGFR2). VEGFR1 is involved in the inflammatory response by stimulating macrophage chemotaxis, ${ }^{11,12}$ as well as vascular permeability and vessel stabilization. ${ }^{13,14}$ In contrast, VEGFR2 mediates angiogenesis ${ }^{15}$ and reduces blood pressure. ${ }^{16}$ The specific roles of VEGFR1 and VEGFR2 in nondiabetic and diabetic kidney disease are not well understood.

Supported by a Juvenile Diabetes Research Foundation-JDRF grant (T.N), a Bogue Research Fellowship from University College London (D.A.L), and a Kidney Research UK Senior Non-Clinical Fellowship (D.A.L)

\section{Accepted for publication March 29, 2011}

Address reprint requests to Takahiko Nakagawa, M.D., Ph.D., Division of Renal Disease and Hypertension, University of Colorado Denver, C281, Aurora, CO 80045. E-mail: Takahiko.Nakagawa@ucdenver.edu. 
One could postulate that VEGFR2 (but not VEGFR1) might have a key role in protecting the kidney from nondiabetic injury by preserving capillary number, because of its angiogenic effects. In diabetic nephropathy, however, VEGFR2 likely has a causal role, as is suggested by studies showing up-regulation of VEGFR2 mRNA expression within weeks of the onset of diabetes in the rat, whereas VEGFR1 was undetectable. ${ }^{17}$ In this situation, a reduction in endothelial NO, which is often observed in diabetic patients, might be a key factor to enhance VEGFR2 signaling for excessive angiogenesis. ${ }^{18,19}$

To begin to understand the roles of VEGFR1 and VEGFR2 in diabetic and nondiabetic kidney diseases, we generated an adeno-associated virus containing a mutant form of VEGF-A that binds only to VEGFR2 (rAAV1Flk-sel) and injected these vectors in normal wild-type (WT) mice and in eNOS-knockout mice (eNOSKO) lacking endothelial NO synthase. Because the role of a specific factor can be more evident in the presence of renal injury than in normal kidney, uninephrectomy (UNx) was performed to accelerate renal injury. We hypothesized that administration of rAAV1-Flk-sel in UNx-WT mice would be protective by enhancing angiogenesis of glomerular and peritubular capillaries. In contrast, we predicted that overexpression of rAAV1-Flk-sel in UNxeNOSKO mice would be deleterious. Overexpression of the VEGF-A mutant for VEGFR1 was unsuccessful in our hands; therefore, here we present the results only for overexpression of Flk-sel.

\section{Materials and Methods}

\section{Experimental Protocol}

Eight-week-old male C57BL/6J-Nos3tm1Unc mice (eNOSKO mice) and background strain C57BL6/J mice (WT mice) weighing 20 to $25 \mathrm{~g}$ were purchased from the Jackson Laboratory (Bar Harbor, ME). Mice were housed under a 12-hour light/dark cycle with free access to food and water. All experiments were performed in accordance with the Animal Care and Use Committee of the University of Florida. Mice ( $n=10$ in each group) were injected intramuscularly with $1.0 \times 10^{10}$ viral particles of either rAAV1-empty vector (EV) or rAAV1-Flk-sel. This level was chosen because a lower dose of $1.0 \times 10^{9}$ viral particles failed to increase serum VEGF-A levels in pilot studies. Flk-sel was provided by Dr. Napoleon Ferrara (Genentech, South San Francisco, CA). The construction and characterization of Flk-sel has been described previously, ${ }^{20}$ with mutations in human $\mathrm{VEGF}_{165}$ at positions D63S/G65M/L66R. ${ }^{16,21,22}$ The rAAV vectors expressing Flk-sel were generated and purified in the Vector Core Laboratory at the University of Florida, using techniques described previously. ${ }^{23}$ Three months later, UNx was used to induce kidney injury. Renal histology was examined at 4 months with blood and urine collected to measure blood urea nitrogen and urinary albumin/creatinine ratio, as described previously. ${ }^{24}$ The scheme of the experimental design is presented in Figure 1.

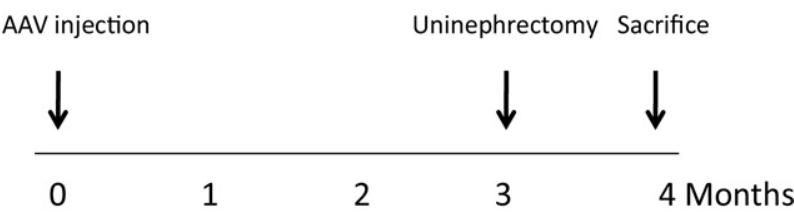

Figure 1. Study protocol. Three months after adeno-associated virus (AAV) injection, UNx was used to induce kidney injury. Mice were sacrificed at 4 months.

\section{Blood Pressure Measurements}

Systolic blood pressure (BP) was assessed every month using a tail-cuff sphygmomanometer (Visitech BP2000; Visitech Systems, Apex, NC). Animals were accustomed to the machine by training, and all measurements were performed at the same time of day.

\section{Serum VEGF-A Measurement}

Serum VEGF-A levels were measured at 3 and 4 months using a commercial human enzyme-linked immunosorbent assay (ELISA) kit (R\&D Systems, Minneapolis, MN) according to the manufacturer's instructions. We had previously confirmed that Flk-sel can be detected by this kit. $^{10}$

IHC

Kidneys were fixed in neutral buffered formalin (10\%), embedded in paraffin, and sectioned at 2- $\mu \mathrm{m}$ thickness. Tubulointerstitial injury was assessed by immunohistochemistry (IHC) with goat anti-human collagen III (SouthernBiotech, Birmingham, AL) and rat antimouse F4/80 (Serotec, Oxford, UK) which detects a subtype of macrophages present predominately in the interstitium. ${ }^{11,25}$ Phenotypic changes in tubular epithelial cells were evaluated using rabbit anti-human $\alpha$-SMA (Abcam, Cambridge, MA) and rabbit anti-human transforming growth factor $\beta 1$ (TGF- $\beta 1$ ) (Santa Cruz Biotechnology, Santa Cruz, CA). Rabbit antimouse collagen IV (Chemicon International, Temecula, CA), rabbit anti-human fibronectin (Sigma-Aldrich, St. Louis, MO), and mouse anti-human CD68 (Abcam; performed on frozen kidney), a marker of macrophage subtypes predominantly expressed in glomeruli, ${ }^{11,25}$ were used to evaluate glomerular injury. For vascular assessment of angiogenic responses, capillary endothelial cells were detected by a rabbit anti-rat thrombomodulin ${ }^{26}$ and rabbit monoclonal human VEGFR2 (Cell Signaling Technology, Danvers, MA). Immunostaining on methyl Carnoy's fixed tissue sections was performed with either rabbit anti-human plateletderived growth factor receptor- $\beta$ (PDGFR $\beta$ ) (Santa Cruz Biotechnology), rabbit anti-human PDGF-B (Ab-1; Oncogene Research Products, La Jolla, CA), or antihuman PDGF-D (kindly provided by ZymoGenetics, Seattle, WA) to examine mesangial damage, followed by ImmPress anti-rabbit Ig polymer detection system (Vector Laboratories, Burlingame CA). To examine cell proliferation, the thymidine analog 5-bromo-2' - de- 


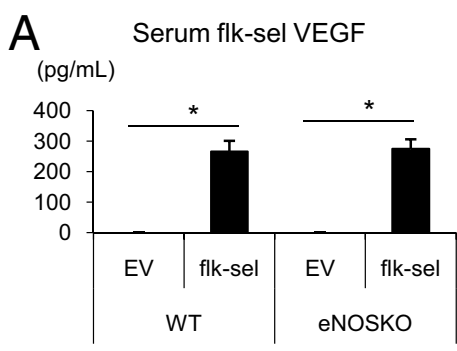

F

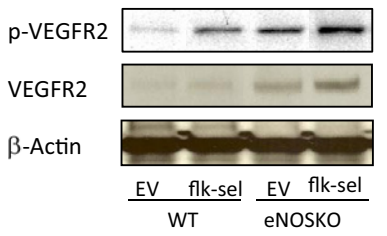

\section{G}

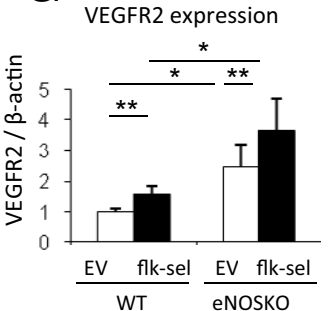

VEGFR1

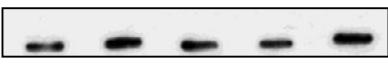

$\beta$-actin

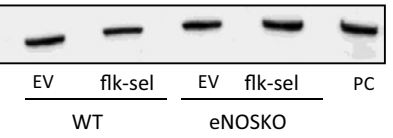

K

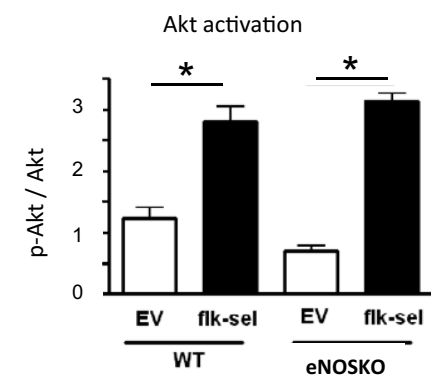

$\mathrm{H}$

VEGFR2 phosphorylation

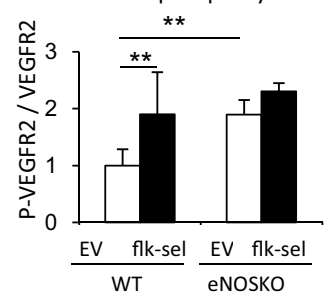

$J_{\text {p-AKT }}$

AKT
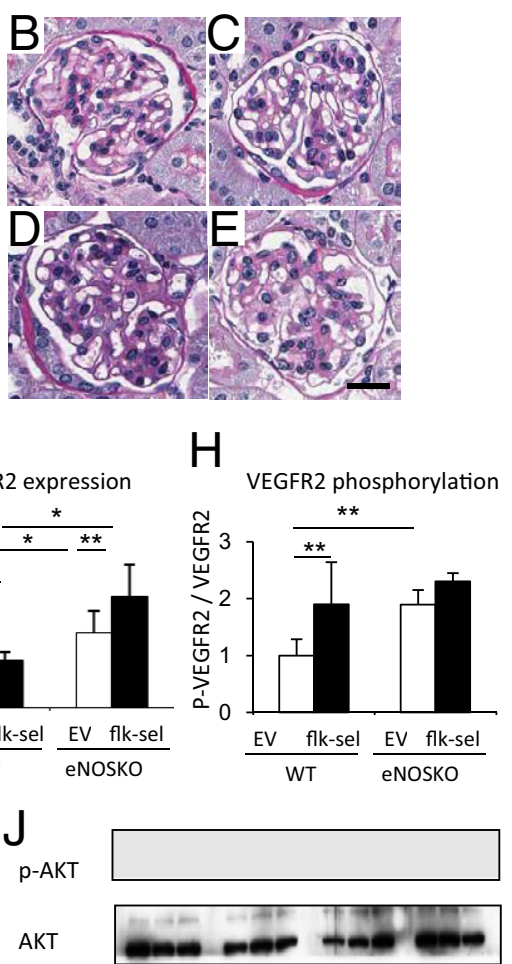

GAPDH

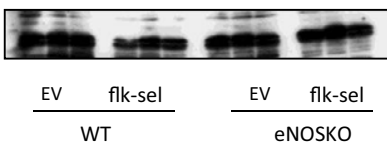

L

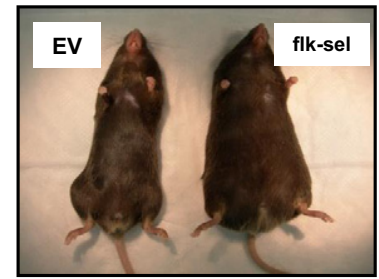

Figure 2. Systemic overexpression of rAAV1Flk-sel. A: Serum human VEGF-A concentrations in WT and eNOSKO mice treated with rAAV1-EV or rAAV1-Flk-sel at 3 months (before UNx). B-E: Representative PAS staining of glomerulus at 3 months from WT mice treated with rAAV1-EV (B) or with rAAV1-Flk-sel (C) and from eNOSKO mice treated with rAAV1-EV (D) or with rAAV1Flk-sel (E). Flk-sel treatment did not change glomerular injury in either type of mouse at 3 months (C and E), compared with control EV treatment (B and $\mathbf{D})$, whereas eNOSKO mice exhibited mild mesangial expansion with either treatment (D and $\mathbf{E}$ ). Scale bar $=20 \mu \mathrm{m} . \mathbf{F}$ : Western blot for renal VEGFR2 in whole kidneys of WT and eNOSKO mice treated with rAAV1-EV or rAAV1-Flk-sel 1 month after UNx. G and $\mathbf{H}$ Quantitative analysis for VEGFR2 expression (VEGFR $2 / \beta$-actin ratio) (G) and phosphorylation (phosphorylated VEGFR2/total VEGFR2) (H). I Western blot for VEGFR1 expression and phosphorylation. J: Western blot for phosphorylated Akt. K: quantification of phosphorylated Akt. L: Representative photographs of eNOSKO mice treated with rAAV1-EV or rAAV1-Flk-sel after UNX. ${ }^{*} P<0.01 ;{ }^{* * *} P<0.05$. Data are expressed as means $\pm \mathrm{SD} ; n=10$ in each group. oxyuridine (BrdU) $(50$ mg/kg; Sigma-Aldrich) was intraperitoneally administered to mice 2 hours before sacrifice. BrdU-positive cells were detected with a rat monoclonal BrdU antibody (Serotec). For all antibodies, color was developed using 3,3'-diaminobenzidine (Dako, Carpinteria, CA). For negative controls, primary antibodies were replaced with species-matched antibodies.

\section{Morphological Quantification}

Periodic acid-Schiff was used to detect morphological characteristics. All glomeruli (>50 glomerular cross-sections per biopsy) and the whole cortical tubulointerstitial area in the axial plane were scanned with the AxioVision image analyzer (Carl Zeiss, Thornwood, NY) and examined. The total dimension of the glomerulus was determined by tracing the

Table 1. General Characteristics of Mice at 3 Months after rAAV Injection

\begin{tabular}{|c|c|c|c|c|}
\hline \multirow[b]{2}{*}{ Characteristic } & \multicolumn{2}{|c|}{ Wild type } & \multicolumn{2}{|c|}{ eNOSKO } \\
\hline & EV & Flk-sel & EV & Flk-sel \\
\hline Body weight $B(\mathrm{~g})$ & $28.0 \pm 2.0$ & $30.0 \pm 2.3^{*}$ & $27.3 \pm 1.7$ & $31.1 \pm 3.3^{+}$ \\
\hline Kidney weight $K(\mathrm{~g})$ & $0.16 \pm 0.014$ & $0.16 \pm 0.021$ & $0.14 \pm 0.011$ & $0.15 \pm 0.011$ \\
\hline$K / B\left(10^{-2}\right)$ & $0.57 \pm 0.05$ & $0.55 \pm 0.08$ & $0.52 \pm 0.05$ & $0.49 \pm 0.06$ \\
\hline
\end{tabular}

${ }^{*} P<0.05$ versus WT-EV

${ }^{\dagger} P<0.01$ versus eNOSKO-EV.

eNOSKO, eNOS knockout; EV, empty vector; Flk-sel, VEGFR2-selective; rAAV, recombinant adeno-associated virus. 
Table 2. General Characteristics of Mice at 1 Month after Uninephrectomy

\begin{tabular}{|c|c|c|c|c|}
\hline \multirow[b]{2}{*}{ Characteristic } & \multicolumn{2}{|c|}{ Wild type } & \multicolumn{2}{|c|}{ eNOSKO } \\
\hline & EV & Flk-sel & EV & Flk-sel \\
\hline Body weight B (g) & $27.2 \pm 1.8$ & $31.6 \pm 3.2^{\star \star *}$ & $26.9 \pm 2.0$ & $36.0 \pm 5.8^{\ddagger}$ \\
\hline Kidney weight K (g) & $0.20 \pm 0.014$ & $0.20 \pm 0.0088$ & $0.17 \pm 0.020$ & $0.19 \pm 0.012^{\dagger}$ \\
\hline$K / B\left(10^{-2}\right)$ & $0.75 \pm 0.05$ & $0.65 \pm 0.05^{\star *}$ & $0.62 \pm 0.06^{* *}$ & $0.53 \pm 0.09$ \\
\hline BUN $(\mathrm{mg} / \mathrm{dL})$ & $28.7 \pm 3.4$ & $34.2 \pm 3.9^{*}$ & $37.8 \pm 2.1^{\text {**** }}$ & $41.9 \pm 3.8^{\dagger}$ \\
\hline u-Alb/u-Cre & $0.12 \pm 0.07$ & $0.48 \pm 0.07^{\star \star \star *}$ & $0.88 \pm 0.39^{\star \star \star}$ & $0.70 \pm 0.50$ \\
\hline
\end{tabular}

${ }^{*} P<0.05,{ }^{* *} P<0.01,{ }^{* * *} P<0.005$, and ${ }^{* * * *} P<0.001$ versus WT-EV.

${ }^{+} P<0.05$ and $\neq P<0.001$ versus eNOSKO-EV.

BUN, blood urea nitrogen; eNOSKO, eNOS knockout; EV, empty vector; Flk-sel, VEGFR2-selective; u-Alb/u-Cre, urine-albumin/urine creatinine ratio; WT, wild type.

outline of the glomerular tuft. The percentage of mesangial matrix (defined as mesangial area) was determined by assessing the PAS-positive area and dividing by the total area of the glomerular tuft. Mesangiolysis was determined as presence of dissolution of the mesangial matrix. ${ }^{24}$ Mesangial cell number was quantified using the Oxford classification, ${ }^{27}$ in which each glomerulus is assessed by the most cellular mesangial area, omitting the mesangial area immediately adjacent to the vascular stalk. In addition, capillary lumen number per glomerulus was also counted, to evaluate angiogenic responses. To examine glomerular lesions, we measured the positive immunostained area in each glomerular cross section for collagen IV, fibronectin, thrombomodulin, and VEGFR2 as an overall percentage of positive area of the glomerular tuft, using computerized image analysis. To quantify endothelial proliferation, the numbers of BrdU-positive cells attached to positive signals for thrombomodulin were counted. Similarly, percentage of positive area for thrombomodulin, collagen III, F4/80, VEGFR2, TGF$\beta 1$, and PDGF-B was examined in whole renal cortex, to assess tubulointerstitial injury. Glomerular $\mathrm{CD}^{+} 8^{+}$cells per square millimeter were counted by examining 50 glomeruli, tubules, and interstitial tissues. in the renal cortex. All quantifications were performed in a blinded manner by two independent investigators (W.S. and T.K.).

\section{Electron Microscopy}

Kidneys were fixed in glutaraldehyde, postfixed with osmium tetroxide, and embedded in Epon 812 medium (Nisshin EM, Tokyo, Japan). Ultrathin sections were examined with a H7100 electron microscope (Hitachi, Ibaraki, Japan).

\section{Western Blot Analysis}

Mouse kidney tissues were snap-frozen in liquid nitrogen for protein isolation. Western blot analysis was performed with 10 to $30 \mu \mathrm{g}$ protein/lane. Blots were incubated with either rabbit monoclonal VEGFR1 antibody (Epitomics, Burlingame, CA), rabbit monoclonal VEGFR2 antibody (Cell Signaling), mouse monoclonal $\beta$-actin antibody (SigmaAldrich), rabbit anti-mouse Akt (both total Akt and phosphorylated Ser473) (Cell Signaling), mouse monoclonal anti-human GAPDH (Santa Cruz Biotechnology), rabbit antiTGF- $\beta 1$ (Cell Signaling), rabbit anti-HIF1 $\alpha$ (Novus Biologicals, Littleton, CO), a rabbit anti-human $\alpha$-SMA anti- body (Abcam), or a mouse anti-human E-cadherin antibody (BD Transduction Laboratories, San Diego, CA), followed by incubation with peroxidase-conjugated rabbit IgG or mouse IgG (DakoCytomation, Carpinteria, CA). Receptor phosphorylation of VEGFR1 was detected using a rabbit anti-phospho-Flt-1 (pY1213) antibody (Millipore-Chemicon International, Temecula, CA). Phosphorylated VEGFR2 was detected by a rabbit anti-mouse-pY949-VEGF R2 antibody (BioSource, Camarillo, CA). Proteins were visualized with an enhanced chemiluminescence detection system (Amersham-GE Healthcare, Piscataway NJ). The density of each band was measured using public domain ImageJ software version $1.41(\mathrm{NIH}$, Bethesda, MD).

\section{Cell Culture}

Human renal proximal tubular (HK2) cells were cultured in keratinocyte-SFM medium containing epidermal growth factor, bovine pituitary extracts, and 10\% serum (Invitrogen, Carlsbad, CA). Ten percent serum was added in order to keep cells healthy during stimulation for 72 hours. After

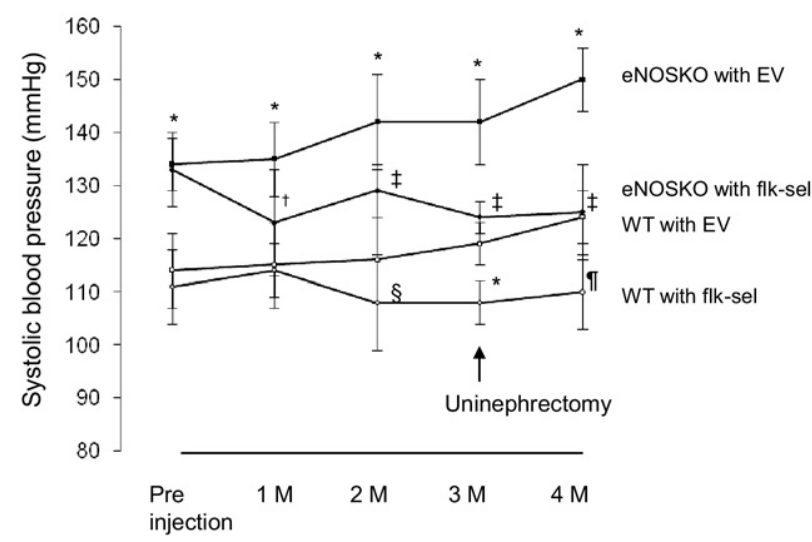

Figure 3. Time course of systolic blood pressure. The rAAV1-Flk-sel treatment lowered blood pressure (BP) beginning at 2 months after injection in WT mice and the change was sustained in UNx-WT mice. BP was significantly higher in eNOSKO mice, compared with WT mice before treatment, but administration of rAAV1-Flk-sel led to a significant decrease 1 month later. The lowering of BP by rAAV1-Flk-sel was also observed in UNxeNOSKO mice. Solid symbols, eNOSKO mice; open symbols, WT mice. Squares, rAAV1-EV; circles, rAAV1-flk-sel. ${ }^{*} P<0.001$ versus WT mice treated with rAAV1-EV; ${ }^{\dagger} P<0.01$ versus eNOSKO mice treated with rAAV1-EV; ${ }^{\ddagger} P<$ 0.001 versus eNOSKO mice treated with rAAV1-EV; ${ }^{\circledR} P<0.05$ versus WT mice treated with rAAV1-EV; ${ }^{\pi} P<0.01$ versus WT mice treated with rAAV1$\mathrm{EV}$. Data are expressed as means $\pm \mathrm{SD} ; n=10$ in each group. 

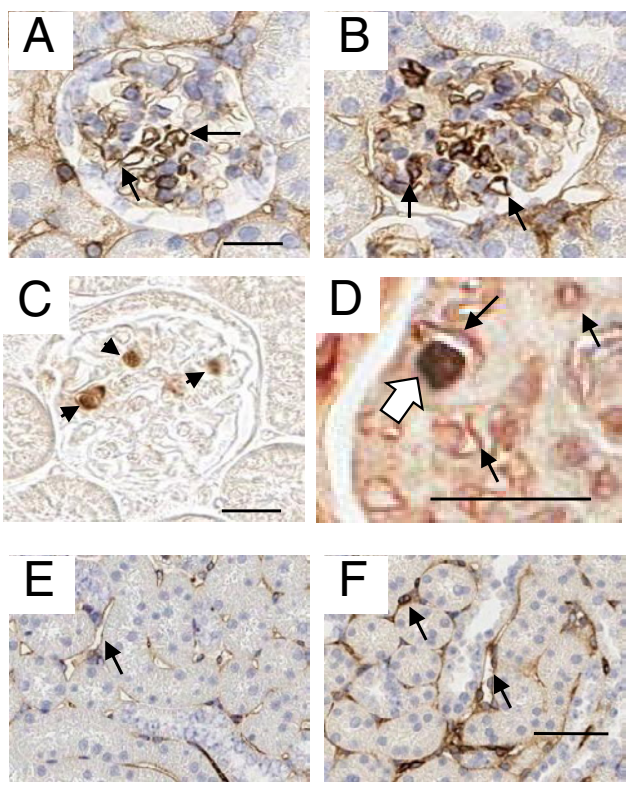

I Thrombomodulin and BrdU

$(+)$ cells in glomerulus

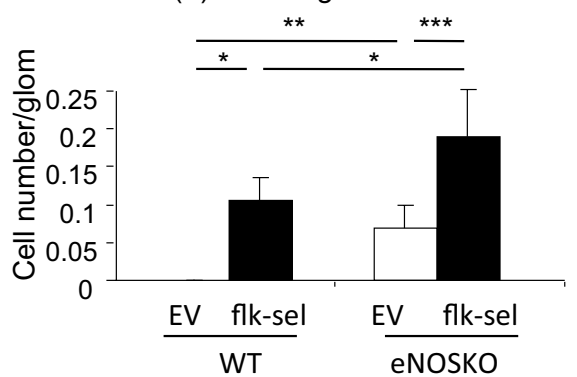

G Thrombomodullin expression in glomerulus

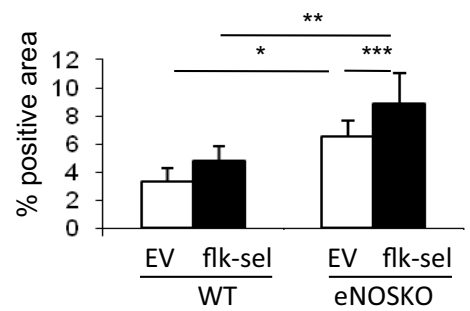

$\mathrm{H} \quad \mathrm{BrdU}(+)$ cells in glomerulus

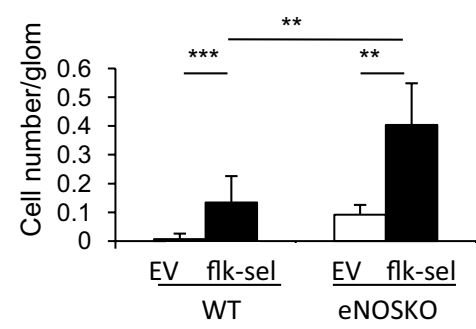

$J$

Thrombomodullin expression in tubulointerstitium

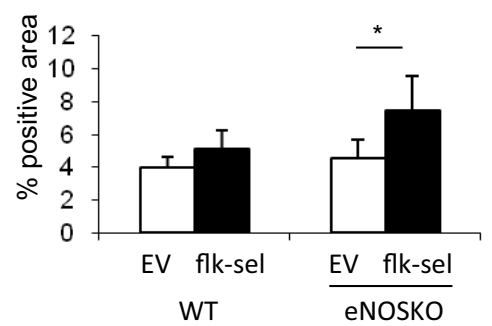

Figure 4. Angiogenic response induced by rAAV1-Flk-sel treatment. A-F: IHC in the glomerulus (A-D) and tubulointerstitium ( and $\mathbf{F}$ ) for thrombomodulin (black arrows in $\mathbf{A}, \mathbf{B}, \mathbf{E}$, and $\mathbf{F}$ ), BrdU (arrow in C) and double staining of thrombomodulin (black arrows) with BrdU (white arrow) (D) at 1 month after UNX in eNOSKO mice treated with rAAV1-EV (A and $\mathbf{E})$ or with rAAV1-Flk-sel (B, C, D, and F). Scale bars $=20 \mu \mathrm{m}$. G-K: Quantitative analysis for thrombomodulin expression (G and $\mathbf{J})$ and number of BrdU-positive cells ( $\mathbf{H}$ and $\mathbf{K}$ ) in the glomerulus $(\mathbf{G}$ and $\mathbf{H})$ and tubulointerstitium ( $\mathbf{J}$ and $\mathbf{K}$ ), and for double staining of thrombomodulin with BrdU in the glomerulus (I). ${ }^{*} P<0.01,{ }^{* *} P<0.001$, and ${ }^{\text {**: }} P<0.05$. Data are expressed as means \pm $\mathrm{SD} ; n=10$ in each group. subconfluence, cells were stimulated by recombinant human VEGF-A 165 (100 ng/mL; PeproTech, Rocky Hill, NJ) in the presence of $10 \%$ serum to examine if VEGF alters the expressions of E-cadherin and $\alpha$-smooth muscle actin $(\alpha-\mathrm{SMA})$, analyzed by Western blotting at 24,48 and 72 hours as described above.

\section{Statistical Analysis}

All values are expressed as means \pm SD. Statistical analysis was performed with unpaired, two-tailed Student's t-tests for single comparisons or analysis of variance with post hoc testing using Tukey's method for multiple comparisons. A $P$ value of $<0.05$ was taken to indicate a significant difference.

\section{Results}

\section{Systemic Overexpression of rAAV1-Flk-sel in WT and eNOSKO Mice}

Initial experiments were performed to determine whether rAAV1-Flk-sel had any effect on WT and eNOSKO mice without renal disease. We administered rAAV1-Flk-sel intramuscularly to both WT and eNOSKO mice and exam- ined them 3 months later. Injection of rAAV1-Flk-sel led to significant elevation of systemic human VEGF-A at 3 months after injection in both mouse types $(P<0.01$ versus rAAV1-EV in WT and eNOSKO mice) (Figure 2A), and levels were similar in both mouse types. eNOSKO mice exhibited mild mesangial expansion (Figure 2D), compared with WT mice (Figure 2B), probably because of eNOS deficiency at this age. ${ }^{28}$ rAAV1-Flk-sel did not alter renal morphology (Figure 2, C and E) or kidney weight in either mouse type (Table 1). Unfortunately, neither blood urea nitrogen nor urine albumin excretion was examined at this point. No remarkable morphological abnormalities were found in spleen, heart, or liver in the mice at this point (data not shown).

Given these findings, we then induced renal injury by performing UNx in both WT and eNOSKO mice at 3 months after rAAV1-Flk-sel injection and examined the mice 1 month later. Both UNx-WT and UNx-eNOSKO mice treated with rAAV1-Flk-sel exhibited an increase in renal total and phosphorylated VEGFR2 (Figure 2, F-H). We did not observe any changes in VEGFR1 levels, and there was no evidence of VEGFR1 phosphorylation in any of the groups of mice (Figure 2I). In further confirmation of VEGFR2 activation, we observed elevated Akt phosphorylation, a downstream target of VEGFR2 signaling, ${ }^{29}$ after Flk-sel treatment in both WT and eNOSKO mice (Figure 2, $\mathrm{J}$ and K). These 

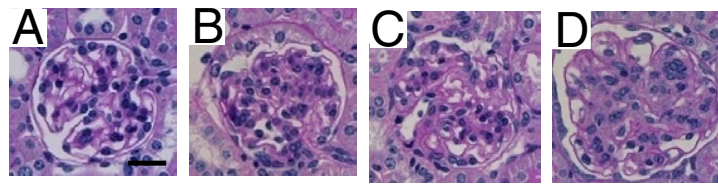

\section{E}

Mesangial expansion after UNx
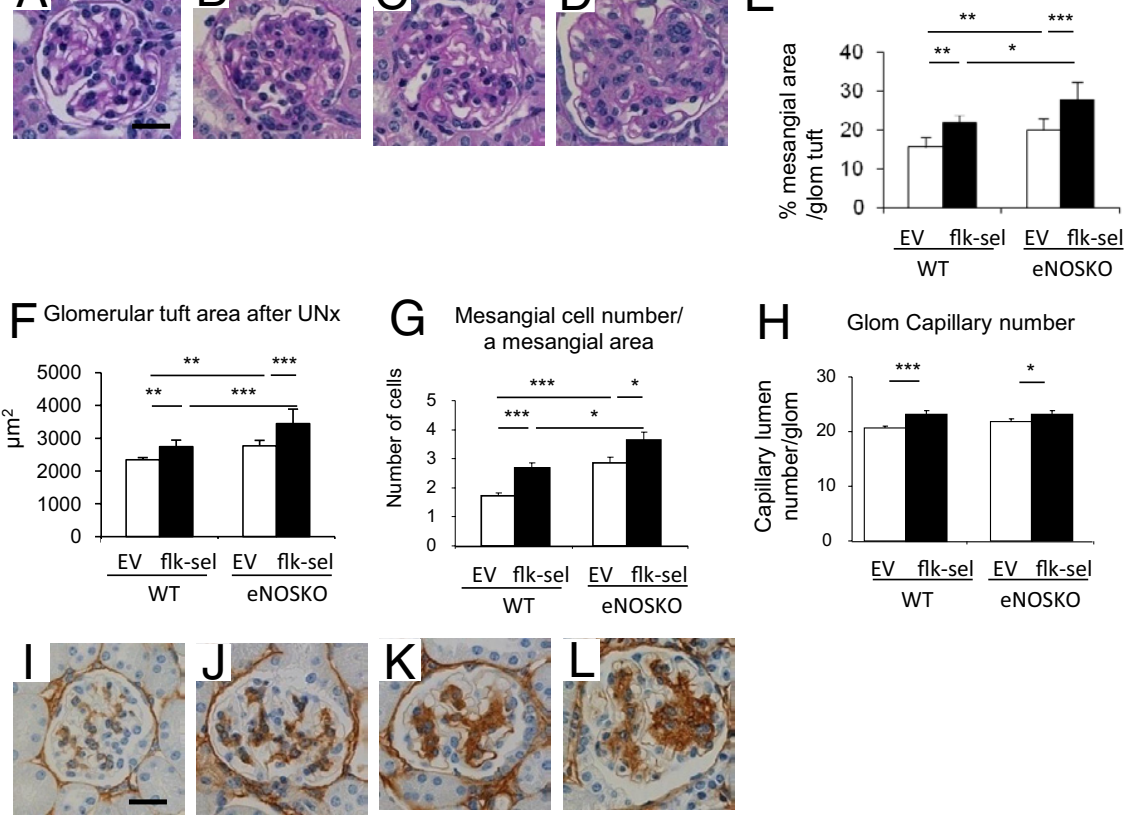

M Collagen IV deposition
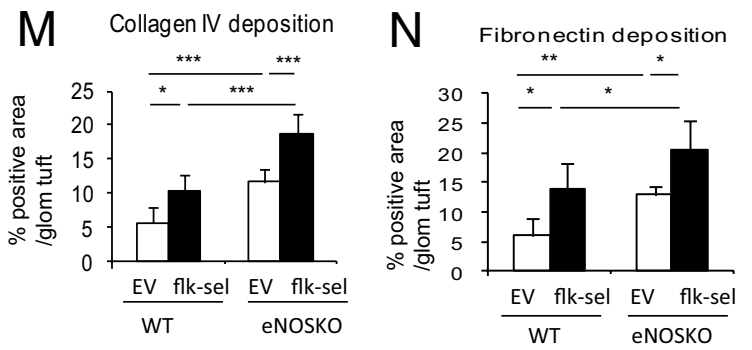

O

Glom CD68 macrophage

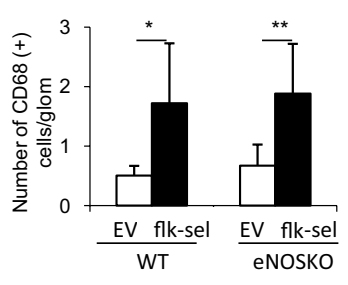

Figure 5. Mesangial expansion in rAAV1-Flk-sel treated mice. A-D: Representative PAS staining of the glomerulus after UNx: UNx-WT mice treated with rAAV1-EV (A) or with rAAV1-Flk-sel (B); UNX-eNOSKO mice treated with rAAV1-EV (C) or with rAAV1-Flk-sel (D). Scale bar $=20$ $\mu \mathrm{m}$. E-H: Quantitative analysis for mesangial expansion $(\mathbf{E})$, glomerular area $(\mathbf{F})$, mesangial cellularity (G), and glomerular (Glom) capillary number $(\mathbf{H})$. I-K: IHC for collagen IV deposition in glomeruli after UNx: UNx-WT mice treated with rAAV1-EV (I) or with rAAV1-Flk-sel $(\mathbf{J})$; UNX-eNOSKO mice treated with rAAV1-EV $(\mathbf{K})$ or with rAAV1-Flk-sel $(\mathbf{L})$. Scale bar $=20 \mu \mathrm{m}$. M-O: Quantitative analysis for $\%$ positive area of deposition of glomerular collagen IV (M) and fibronectin (N), with number of $\mathrm{CD} 68^{+}$cells in the glomerulus (Glom) $(\mathbf{O})$. ${ }^{*} P<0.01,{ }^{* *} P<$ 0.05 , and ${ }^{* * * * *} P<0.001$. Data are expressed as means $\pm \mathrm{SD} ; n=10$ in each group. data suggest that renal VEGFR2 was successfully stimulated by rAAV1-Flk-sel administration in this model.

rAAV1-Flk-sel overexpression was associated with increased body weight in both UNx-WT and UNx-eNOSKO mice, compared with rAAV1-EV treatment (Figure $2 \mathrm{~L}$ and Table 2). Although previous studies indicated that VEGF-A causes renal hypertrophy, ${ }^{30,31}$ rAAV1-Flk-sel treatment did not alter kidney size after UNx; instead, the ratio of kidney to body weight was reduced (Table 2). Although overexpression of rAAV1-Flk-sel was well tolerated by both WT and eNOSKO animals, it did lead to some changes in renal function after UNx (Table 2). UNx-WT mice treated with rAAV1-Flk-sel had elevated blood urea nitrogen and urinary albumin excretion, compared with those treated with rAAV1-EV. Blood urea nitrogen was higher in UNx-eNOSKO than in UNx-WT animals, and rAAV1-Flk-sel treatment further enhanced levels. rAAV1-Flk-sel administration to UNx-eNOSKO mice did not lead to alterations in albumin excretion.

\section{Role of VEGFR2 in Blood Pressure in WT and eNOSKO Mice}

Consistent with reports that VEGFR2 is responsible for reducing $B P,{ }^{16}$ we found rAAV1-Flk-sel WT mice had lower systemic BP than rAAV1-EV WT mice (Figure 3), both before UNx and at 1 month after. Given that the effect of VEGF-A on lowering BP is thought to be secondary to stimulating endothelial $\mathrm{NO},{ }^{32}$ we had hypothesized that BP would not be lowered in the eNOSKO mouse. However, BP was unexpectedly lowered in eNOSKO mice, with rAAV1-Flk-sel overexpression before and at 1 month after UNx (Figure 3).

\section{Increased Angiogenesis in the Kidneys of Flk-sel Overexpressing Mice}

One of the key actions of VEGFR2 is to enhance endothelial cell proliferation. We therefore examined BrdU incorporation, as a marker of cell proliferation, ${ }^{33}$ and thrombomodulin, as a specific endothelial cell marker ${ }^{24,34}$ (Figure 4). Administration of rAAV1-Flk-sel tended to increase thrombomodulin-positive endothelial cells in glomeruli and tubulointerstitium in UNx-WT mice. This effect was significantly pronounced in the UNx-eNOSKO mice (Figure 4, G and J). The increase in endothelial cells was associated with induction of proliferating cells labeled with BrdU (Figure 4, $\mathrm{H}$ and $\mathrm{K})$. Double staining of thrombomodulin with BrdU confirmed an increase in proliferating endothelial number by rAAV1-Flk-sel, which was enhanced in UNxeNOSKO animals (Figure 4I). Counts of glomerular capillaries were also elevated by rAAV1-Flk-sel in both 

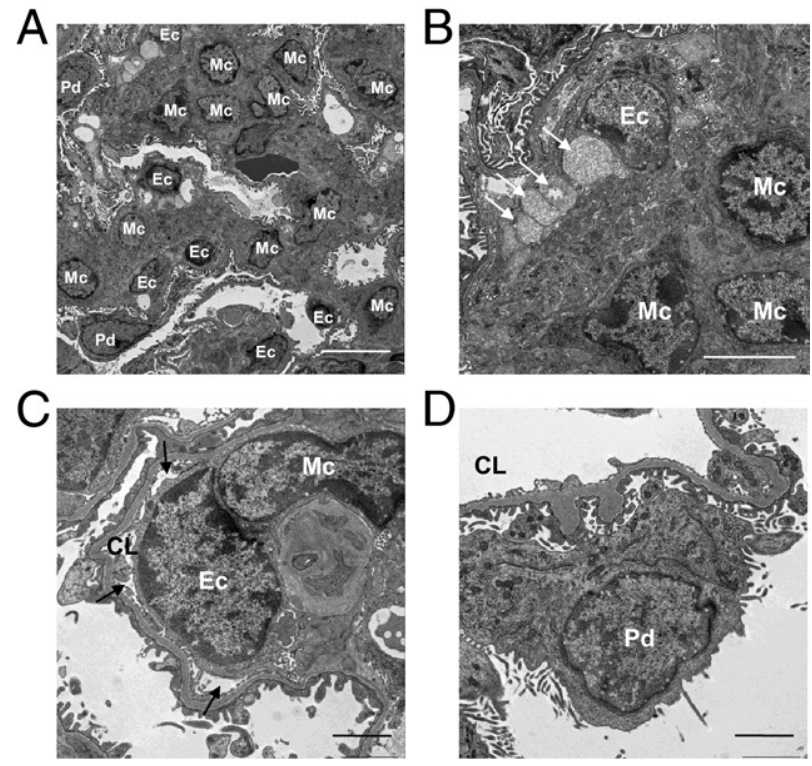

\section{$\mathrm{E}$}

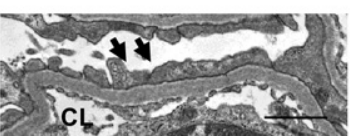

Figure 6. Glomerular ultrastructure in UNx-eNOSKO mice treated with rAAV1-Flk-sel. Representative electron micrographs demonstrate increased mesangial cell (Mc) number (A) and extracellular matrix deposition (A and $\mathbf{B})$ in glomeruli of UNX-eNOSKO mice treated with rAAV1-Flk-sel. B: Vacuolization is observed in the subendothelial space (arrows). C: A narrowing of glomerular capillary lumen (CL) (arrows) due to swelling of the endothelial cell (Ec) with partial mesangial interposition is present in UNX-eNOSKO mice treated with rAAV1-Flk-sel treatment. In contrast, podocytes (Pd) appear normal (D), although some foot processes are fused (arrows) (E).

UNx-WT and UNx-eNOSKO mice, but a lack of eNOS had no effect on this parameter (Figure $5 \mathrm{H}$ ).

\section{De Novo Mesangial Proliferative Glomerular Injury}

We had postulated that overexpression of rAAV1-Flksel would be beneficial in UNx-WT mice, because of its ability to lower BP and stimulate angiogenesis; however, unexpectedly, a marked mesangial expansion and proliferation were induced. rAAV1-Flk-sel induced mesangial expansion, glomerular hypertrophy, and mesangial proliferation in UNx-WT and UNx-eNOSKO mice (Figure 5, A-G), but there was no alteration in mesangiolysis (data not shown). Enhanced mesangial expansion was accompanied by elevation in collagen IV and fibronectin deposition (Figure 5, I-N). An increase in $\mathrm{CD}^{+} 8^{+}$glomerular macrophages after rAAV1-Flk-sel treatment in both UNx-WT and UNxeNOSKO mice also likely contributed to the high cellularity in the mesangium. However, a lack of eNOS had no effect on this response (Figure 50).

Electron microscopy confirmed these findings, with a marked increase of mesangial cells (Figure 6A) and subendothelial vacuolization (Figure 6B) in UNxeNOSKO mice overexpressing rAAV1-Flk-sel. Narrowing of the capillary lumen was concomitant with endothelial swelling and mesangial cell proliferation and interposition in UNx-eNOSKO mice treated with rAAV1Flk-sel (Figure 6C). Podocyte cell bodies had a normal appearance, whereas focal foot process fusion was occasionally observed in UNx-eNOSKO mice, with or without treatment (Figure 6, D and $\mathrm{E}$ ).

The PDGF-B and -D isoforms are key cytokines in regulating mesangial cell proliferation. ${ }^{35}$ We found that PDGF-D was barely expressed in glomeruli of UNx-WT mice but was significantly induced by rAAV1-Flk-sel treatment (Figure 7, A and B). A lack of eNOS itself also induced mesangial PDGF-D expression, compared with nontreated UNx-WT mice, and this was greater in the presence of $\mathrm{rAAV1-Flk-sel} \mathrm{overexpression} \mathrm{(Figure}$ $7, C$ and D). PDGF-B and PDGF- $\beta$ R expression mirrored the PDGF-D staining patterns in these mice (Figure $7, \mathrm{E}-\mathrm{L})$. The observation that overexpression of rAAV1-Flk-sel resulted in mesangial expansion and proliferation led us to closely evaluate the sites of expression of VEGFR2 in this model. Although it is predominantly expressed in endothelial cells, ${ }^{36}$ VEGFR2 has been reported in mesangial cells of diseased glomeruli, ${ }^{37}$ and VEGFR2 was found to be induced in the mesangial cells of UNx-WT mice after rAAV1-Flk-

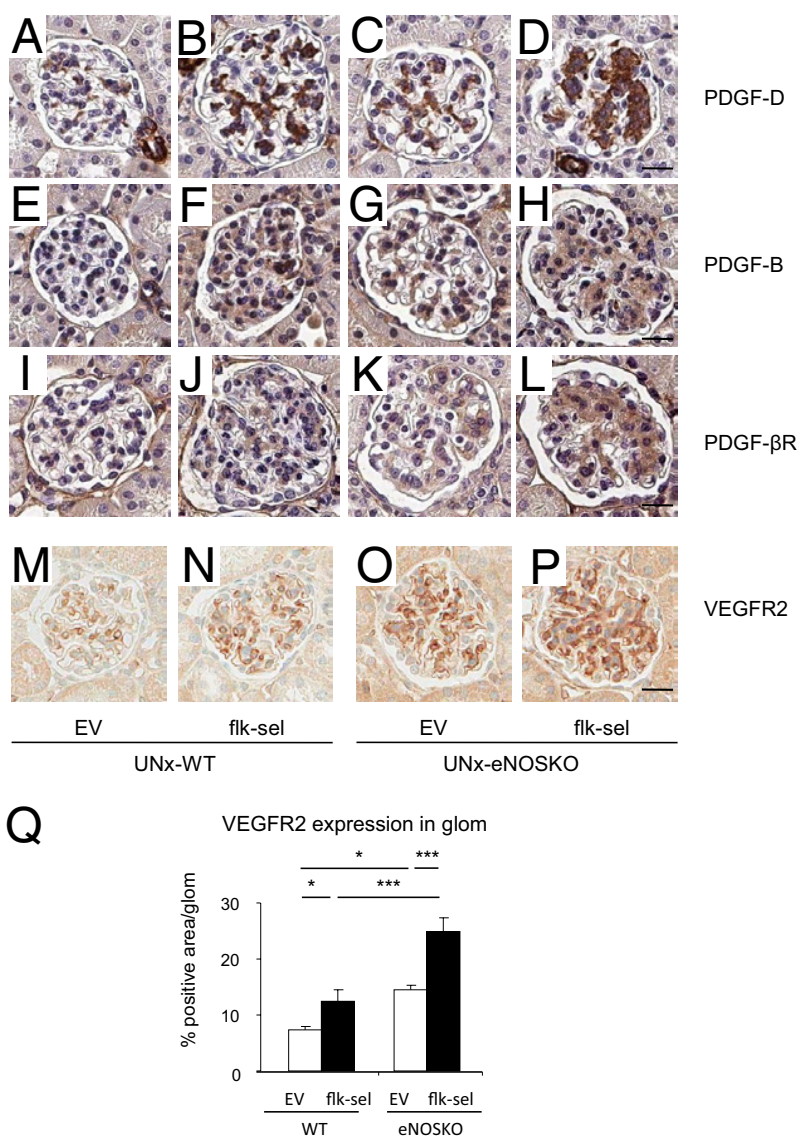

Figure 7. Glomerular expression of PDGF family and VEGFR2. A-P: Staining (brown) for PDGF-D, PDGF-B, PDGF- $\beta$ R, and VEGFR2 in glomeruli of four groups of mice 1 month after UNx: UNX-WT mice treated with rAAV1-EV $(\mathbf{A}, \mathbf{E}, \mathbf{I}$, and $\mathbf{M})$ or with rAAV1-Flk-sel $(\mathbf{B}, \mathbf{F}, \mathbf{J}$, and $\mathbf{N})$; UNX-eNOSKO mice treated with rAAV1-EV $(\mathbf{C}, \mathbf{G}, \mathbf{K}$, and $\mathbf{O})$ or with rAAV1-Flk-sel $(\mathbf{D}, \mathbf{H}, \mathbf{L}$, and P). Scale bars $=20 \mu \mathrm{m}$. Q: Quantitative analysis for $\%$ positive VEGFR2 expression in glomerulus (glom). ${ }^{*} P<0.01$, ${ }^{* * * *} P<0.001$. Data are expressed as means $\pm \mathrm{SD} ; n=10$ in each group. 

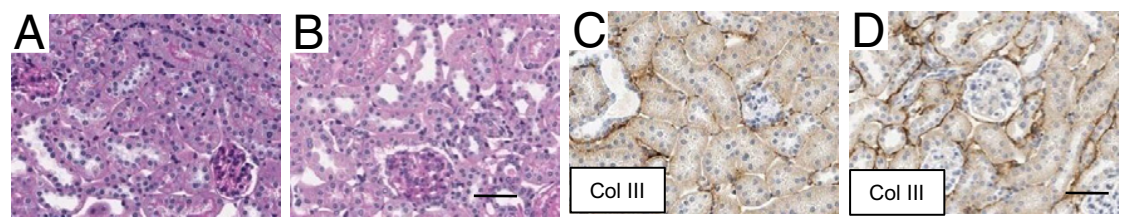

$E$

Collagen III deposition in
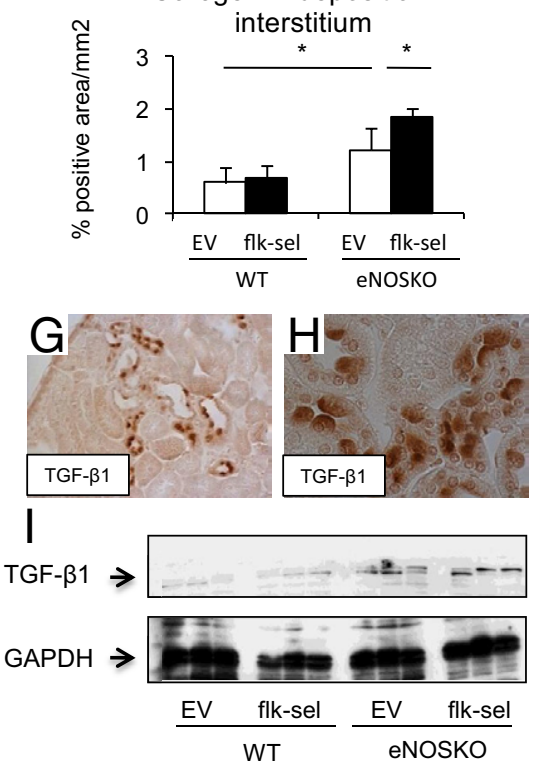

N TGF- $\beta 1$ expression (WB)
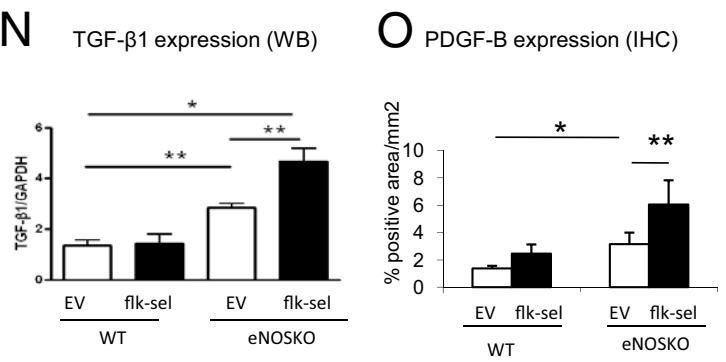

$\mathrm{P}$

VEGFR2 expression (IHC)
Figure 8. Tubulointerstitial injury, A: UNxeNOSKO mice treated with rAAV1-EV shows no evidence of tubular injury. B: Tubular injury is apparent under PAS staining in UNx-eNOSKO mice treated with rAAV1-Flk-sel. C and D: IHC for collagen III in UNX-eNOSKO mice treated with rAAV1-EV (C) or with rAAV1-Flk-sel (D). E and F: Quantitative analysis of collagen III deposition (E) and F4/80-positive macrophage infiltration $(\mathbf{F})$. $\mathbf{G}$ and $\mathbf{H}$ : TGF- $\beta 1$ expression in $\mathrm{UNx}-$ eNOSKO mice treated with rAAV1-Flk-sel is detected in some tubular epithelial cells unde low-power magnification $(\mathbf{G}, \times 200)$, whereas a high power view revealed TGF- $\beta 1$ located in the apical epithelial membrane $(\mathbf{H}, \times 630)$. I and $\mathbf{N}$ Western blotting (WB) of renal cortex for TGF- $\beta 1$ $(\mathbf{H})$ and its quantification ( $\mathbf{N})$. In terms of PDGF-B expression, compared with UNxeNOSKO mice treated with rAAV1-EV $(\mathbf{J})$, PDGF-B staining (arrow) is enhanced in UNxeNOSKO mice treated with rAAV1-Flk-sel (K), as shown by its quantification $(\mathbf{O})$. VEGFR2 is expressed (arrows) in UNx-eNOSKO mice treated with rAAV1-EV (L), and expression is pronounced in tubular cells of UNX-eNOSKO mice treated with rAAV1-Flk-sel (M). P: Quantification of IHC for VEGFR2. ${ }^{*} P<0.05,{ }^{* *} P<0.001$. Data are expressed as means $\pm \mathrm{SD} ; n=10$ in each group. Scale bars $=50 \mu \mathrm{m}$. sel treatment (Figure 7, M, N, and Q). Furthermore, VEGFR2 was also expressed in UNx-eNOSKO mice and was greatly enhanced with rAAV1-Flk-sel treatment (Figure 7, O, P, and Q). Study with isolated glomeruli would be required to confirm these findings.

\section{Tubulointerstitial Injury}

Mild tubulointerstitial injury was observed in UNxeNOSKO mice treated with rAAV1-EV, as evidenced by tubular dilation (Figure 8, A and B) and atrophy accompanied by detachment of tubular epithelial cells (data not shown); the injury was more prominent in UNx-eNOSKO mice treated with rAAV1-Flk-sel. Collagen III deposition was more severe in UNx-eNOSKO mice treated with rAAV1-EV than in UNx-WT mice treated with rAAV1-EV, whereas $\mathrm{rAAV} 1-\mathrm{Flk}$-sel treatment significantly induced interstitial collagen III deposition in UNx-eNOSKO mice (Figure 8, C-E). F4/80-positive macrophage infiltration was induced by rAAV1-Flk-sel treatment in both eNOSKO and WT mice (Figure 8F).

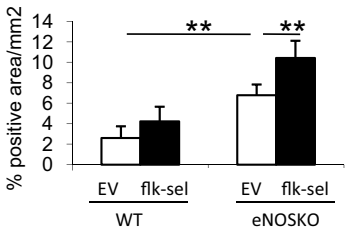

Expression of TGF- $\beta 1$ (Figure 8, G and H), PDGF-B (Figure $8, \mathrm{~J}, \mathrm{~K}$, and $\mathrm{O}$ ), and VEGFR2 (Figure $8, \mathrm{~L}, \mathrm{M}$, and P) was increased in damaged tubular epithelial cells in UNxeNOSKO and was enhanced with rAAV1-Flk-sel treatment. In particular, TGF- $\beta 1$ expression was located in apical membrane of damaged tubular cells (Figure $8 \mathrm{H}$ ); total protein levels of TGF- $\beta 1$ were increased in whole kidney lysates of UNx-eNOSKO animals and were further enhanced by Flk-sel stimulation (Figure 8, I and N).

Strikingly, the damaged tubular epithelial cells expressed $\alpha$-SMA, a marker of myofibroblast in UNxeNOSKO mice, which was further enhanced by rAAV1Flk-sel treatment (Figure 9, A and B). Consistently, total $\alpha$-SMA expression in the kidney as indicated by Western blotting was elevated in these groups (Figure 9, C and D). To determine whether VEGF directly induces $\alpha$-SMA on tubular epithelial cells, we conducted an in vitro study with HK2 cells. Consistent with our in vivo data, we found that VEGF-A induced $\alpha$-SMA at 48 and 72 hours. In addition, VEGF-A also reduced E-cadherin expression, an epithelial cell marker (Figure 9E). 

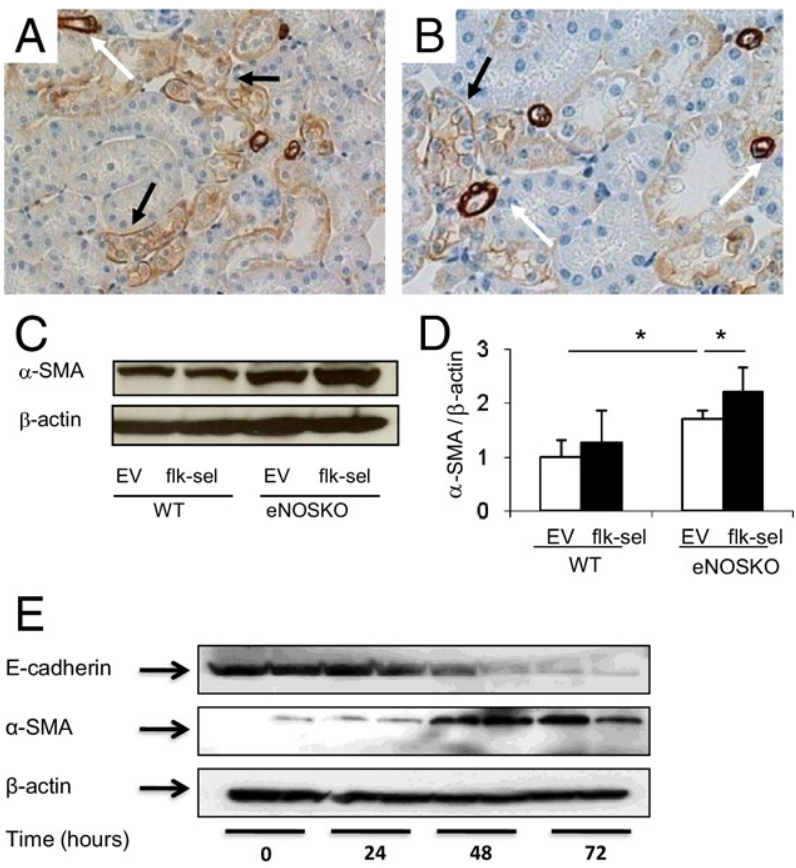

Figure 9. Expression of myofibroblasts markers in tubular epithelial cells. A and B: Expression of $\alpha$-SMA in renal cortex (A, original magnification $\times 400$ ) and medulla $(\mathbf{B}$, original magnification $\times 400)$ of UNX-eNOSKO mice treated with rAAV1-Flk-sel is detected by IHC. $\alpha$-SMA is strongly expressed in vascular smooth muscle cells in arterioles and arteries (white arrow), whereas weaker signal (black arrow) is seen in tubular epithelial cells. C and D: Western blotting for $\alpha$-SMA and its quantification. E: VEGF (100 $\mathrm{ng} / \mathrm{mL}$ ) induces $\alpha$-SMA expression at 48 and 72 hours, accompanied by a reduction in E-cadherin in HK2 cells, confirming the in vivo findings. ${ }^{*} P<$ 0.05 . Data are expressed as means $\pm \mathrm{SD} ; n=10$ in each group.

A proposed mechanism accounting for effects of specific VEGFR-2 stimulation is presented in Figure 10.

\section{Discussion}

In the present study, the primary finding was that supraphysiological activation of VEGFR2 before UNx predisposed WT mouse kidneys to renal injury. This finding was surprising, because VEGF-A administration has been reported to be beneficial in several types of renal injury. 3,4,6,7 A potential explanation for this discrepancy is the timing of VEGF-A treatment and whether this maneuver occurs before or after onset of renal injury. The progression of renal injury is usually associated with a loss of capillaries, and so preventing capillary loss by VEGF-A might be beneficial. In contrast, the present study examined the effect of VEGF-A therapy performed before the onset of renal injury. Here, VEGF-A overexpression has the potential to lead to excessive numbers of vessels, which could be structurally and functionally immature ${ }^{38}$ and the presence of which may augment renal disease progression.

We found that stimulation of VEGFR2 caused abnormal angiogenesis in the kidney, and VEGF-A also contributed to the development of other renal injury features, including mesangial expansion, macrophage influx, and tubulointerstitial injury, in particular in the presence of $\mathrm{NO}$ deficiency. Of note, VEGF-A acting through the activation of VEGFR2, but not VEGFR1, is known to play a key role in diabetic nephropathy, ${ }^{17}$ which is characterized by phenotypes similar to those observed in the present study. Others have shown that VEGF-A inhibition prevents an increase in glomerular volume in diabetic animals. $^{8,9,30}$ It is therefore possible that high VEGF-A, in addition to high glucose, could potentially contribute not only to the development of angiogenesis but to other features of diabetic glomerular injury. In this regard, giving Flk-sel therapy to diabetic patients might lead to further deterioration in diabetic nephropathy.

There are several potential mechanisms for how VEGF-A can alter mesangial cell biology. VEGF-A may directly bind to VEGFR2 expressed on mesangial cells. Previous studies have shown that VEGFR2 is exclusively expressed in endothelial cells in the normal mouse glomerulus, ${ }^{36}$ but we found VEGFR2 expression in the mesangial area of UNx-WT mice after Flk-sel treatment. Furthermore, eNOS deficiency also induced VEGFR2 expression, which was enhanced with Flk-sel treatment in UNx-eNOSKO mice. Given that Thomas et al ${ }^{37}$ also demonstrated VEGFR2 expression in mesangium in human proliferative glomerulonephritis, these cells may express VEGFR2 under certain conditions. The precise mechanism for elevated VEGFR2 in this model is unclear, but one possibility is that UNx leads to a positive feedback loop and hence to autocrine stimulation of VEGFR-2. ${ }^{39}$

Mesangial proliferation induced by Flk-sel therapy was associated with alterations in expression of PDGF/ PDGFR, which are potent mitotic factors for mesangial cells. ${ }^{40}$ This finding is consistent with previous report. ${ }^{41}$ Notably, VEGF-A is capable of signaling through PDGFRs, ${ }^{42}$ and so our VEGF-A mutant might directly stimulate PDGF pathways in our animals, leading to alterations in mesangial cell biology. Future studies are required to address this issue.

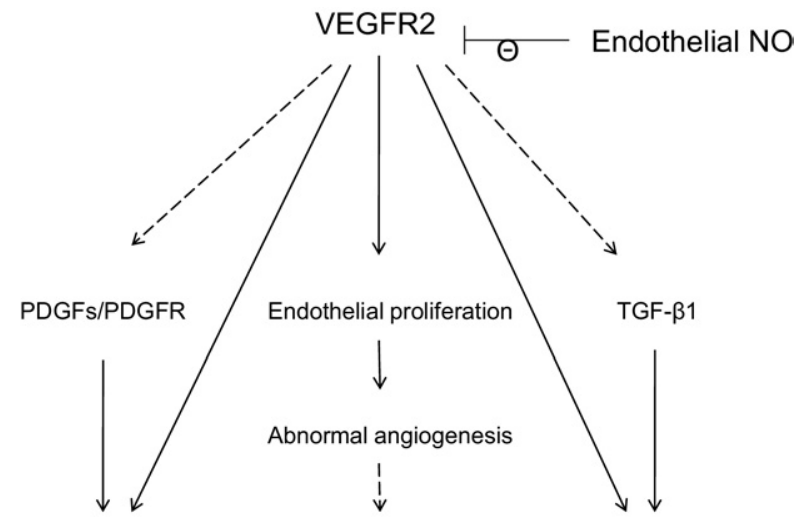

Mesangial proliferation ECM deposition EMT like lesion

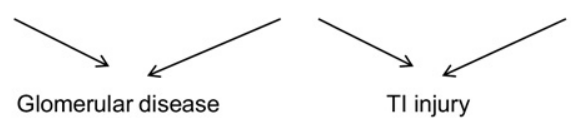

Figure 10. A proposed mechanism by which VEGFR2 stimulation predisposes to renal injury in the mouse kidney. EMC, extracellular matrix; EMT, epithelial-mesenchymal transition; NO, nitric oxide; PDGF, platelet-derived growth factor; PDGFR, platelet-derived growth factor receptor; TGF- $\beta 1$, transforming growth factor $\beta 1$; TI, tubulointerstitial; VEGFR2, vascular endothelial growth factor receptor 2. Dashed lines indicate a proposed pathway that was not demonstrated in the present study. 
The role of VEGFR2 in podocytes is controversial. Veron et al ${ }^{43}$ documented that overexpression of VEGF-A in podocytes stimulates VEGFR2 expression in autocrine fashion, whereas our experiments showed that VEGFR2 stimulation did not affect podocyte structure. The most likely explanation for this discrepancy is that VEGF-A was locally overexpressed in podocytes themselves in the Veron et $\mathrm{al}^{43}$ study, but Flk-sel levels were increased in the circulation in the present study. The concentration of Flk-sel could presumably be reduced when it reaches podocyte cells. Alternatively, our findings are supported also by a recent study showing that VEGFR2-knockout podocytes do not lead to any glomerular abnormalities in mice up to 6 months of age, indicating that podocyte VEGFR2 is biologically inactive. ${ }^{44}$

A striking finding in the present study was that Flk-sel overexpression led to expression of $\alpha$-SMA in some epithelial cells in damaged tubules. This was confirmed by our in vitro study, which showed that VEGF-A caused a reduction of the E-cadherin expression (a marker of epithelial cells) and an induction of $\alpha$-SMA expression (a marker of mesenchymal cells), suggesting that VEGF might cause a phenotypic change in tubular cells. Caution is advised in interpreting these data, however, because recent studies have challenged the existence of this epithelial-mesenchymal transition in kidney disease. ${ }^{45}$

In opposition to our predictions, and despite the fact that inflammatory reactions after VEGF-stimulation are thought to be attributed to VEGFR1, not VEGFR2, ${ }^{11,12}$ selective VEGFR2 stimulation elevated macrophage infiltration as assessed by F4/80 and CD68 staining, regardless of eNOS expression, The renal macrophage infiltration observed in the present study was unlikely to be due to direct VEGFR2 stimulation, but probably was due to an indirect effect from other cytokines that may be expressed in injured kidneys.

We found that stimulation of VEGFR2 caused renal injury, but without aggravation of albuminuria. This discordance between urine albumin excretion and renal function has been found also in several clinical studies. The ONTARGET study showed that stronger inhibition of the renin-angiotensin system accelerated renal disease progression, whereas urinary protein excretion was reduced. ${ }^{46}$ Given these facts, perhaps urine albumin excretion and renal injury are not always associated. Future study would be warranted to address this issue.

VEGFR2 stimulation has been shown to lower BP by stimulating endothelial NO production. ${ }^{16,32}$ In contrast, the present study documented that overexpression of Flk-sel reduced systemic BP, despite eNOS deficiency. This suggests that alternative factors that contribute to BP regulation, including endothelial-derived hyperpolarizing factor, ${ }^{47-50}$ could be altered by Flk-sel.

Finally, we noted that VEGFR2 stimulation resulted in an increase in weight in our mice. Although the present study did not address the mechanism or assess lipid profiles, perhaps an increase in angiogenesis on fat tissue was involved, in addition to adipogenesis. ${ }^{51,52} \mathrm{Be}$ cause adipose tissue is known to produce cytokines and adipokines, it remains possible that such factors may even contribute to renal disease progression.

There are some caveats for the present study. First serum levels of Flk-sel could be too high to provide insights into the actual pathological role of VEGFR2 in kidney disease. Second, we need to consider whether our animal model replicates human renal disease. However, given that in diabetic nephropathy VEGF-A expression is up-regulated early, ${ }^{17}$ before renal disease progression, the insights provided by the present study might help us understand pathogenesis of the development of diabetic nephropathy and potentially other renal diseases if they are associated with a reduction of NO bioavailability. Third, discrepancies in endothelial cell analysis should be noted. Although thrombomodulin staining was significantly greater in Flk-sel eNOSKO mice than in Flk-sel WT mice, this difference was not observed in glomerular capillary number. It is possible that small changes in endothelial cell proliferation might not necessarily translate to an increase in capillary number. Alternatively, thrombomodulin staining may be a more sensitive detector of endothelial cells, compared with counting capillary lumens. Finally, thrombomodulin could be expressed in nonendothelial cells in this model. ${ }^{53}$ This last possibility seems unlikely, however, given that thrombomodulin is associated with the endothelial marker CD34 in eNOSKO mice. ${ }^{24}$ Last of all, IHC was used to assess the levels of soluble factors such as PDGF. This may not be the most reliable method, because of secretion of these molecules; other strategies, such as glomerular isolation, should be considered in the future.

In conclusion, the present study documented that VEGFR2 stimulation before renal insult can predispose to an acceleration of renal disease, especially in the presence of endothelial NO deficiency.

\section{Acknowledgments}

We thank Mr. Norihiko Suzuki (Nagoya University, Nagoya, Japan) for excellent technical assistance and Dr. Richard J. Johnson (University of Colorado Denver, Denver, CO) for precious advice and critical review of this manuscript.

\section{References}

1. Kang DH, Anderson S, Kim YG, Mazzalli M, Suga S, Jefferson JA, Gordon KL, Oyama TT, Hughes J, Hugo C, Kerjaschki D, Schreiner GF, Johnson RJ: Impaired angiogenesis in the aging kidney: vascular endothelial growth factor and thrombospondin-1 in renal disease. Am J Kidney Dis 2001, 37:601-611

2. Kang DH, Joly AH, Oh SW, Hugo C, Kerjaschki D, Gordon KL, Mazzali M, Jefferson JA, Hughes J, Madsen KM, Schreiner GF, Johnson RJ: Impaired angiogenesis in the remnant kidney model: I. Potential role of vascular endothelial growth factor and thrombospondin-1. J Am Soc Nephrol 2001, 12:1434-1447

3. Suga S, Kim YG, Joly A, Puchacz E, Kang DH, Jefferson JA, Abraham JA, Hughes J, Johnson RJ, Schreiner GF: Vascular endothelial growth factor (VEGF121) protects rats from renal infarction in thrombotic microangiopathy. Kidney Int 2001, 60:1297-1308

4. Kang DH, Hughes J, Mazzali M, Schreiner GF, Johnson RJ: Impaired angiogenesis in the remnant kidney model: II. Vascular endothelial 
growth factor administration reduces renal fibrosis and stabilizes renal function. J Am Soc Nephrol 2001, 12:1448-1457

5. Yuan HT, Li XZ, Pitera JE, Long DA, Woolf AS: Peritubular capillary loss after mouse acute nephrotoxicity correlates with down-regulation of vascular endothelial growth factor-A and hypoxia-inducible factor-1 alpha. Am J Pathol 2003, 163:2289-2301

6. Kim YG, Suga SI, Kang DH, Jefferson JA, Mazzali M, Gordon KL, Matsui K, Breiteneder-Geleff S, Shankland SJ, Hughes J, Kerjaschki D, Schreiner GF, Johnson RJ: Vascular endothelial growth factor accelerates renal recovery in experimental thrombotic microangiopathy. Kidney Int 2000, 58:2390-2399

7. Shimizu A, Masuda $Y$, Mori T, Kitamura $H$, Ishizaki M, Sugisaki $Y$, Fukuda Y: Vascular endothelial growth factor 165 resolves glomerular inflammation and accelerates glomerular capillary repair in rat antiglomerular basement membrane glomerulonephritis. J Am Soc Nephrol 2004, 15:2655-2665

8. de Vriese AS, Tilton RG, Elger M, Stephan CC, Kriz W, Lameire NH: Antibodies against vascular endothelial growth factor improve early renal dysfunction in experimental diabetes. J Am Soc Nephrol 2001, 12:993-1000

9. Flyvbjerg A, Dagnaes-Hansen F, De Vriese AS, Schrijvers BF, Tilton $R G$, Rasch R: Amelioration of long-term renal changes in obese type 2 diabetic mice by a neutralizing vascular endothelial growth factor antibody. Diabetes 2002, 51:3090-3094

10. Nakagawa T, Sato W, Sautin YY, Glushakova O, Croker B, Atkinson MA, Tisher CC, Johnson RJ: Uncoupling of vascular endothelia growth factor with nitric oxide as a mechanism for diabetic vasculopathy. J Am Soc Nephrol 2006, 17:736-745

11. Sato W, Kosugi T, Zhang L, Roncal CA, Heinig M, Campbell-Thompson M, Yuzawa Y, Atkinson MA, Grant MB, Croker BP, Nakagawa T: The pivotal role of VEGF on glomerular macrophage infiltration in advanced diabetic nephropathy. Lab Invest 2008, 88:949-961

12. Barleon B, Sozzani S, Zhou D, Weich HA, Mantovani A, Marmé D: Migration of human monocytes in response to vascular endothelial growth factor (VEGF) is mediated via the VEGF receptor flt-1. Blood 1996, 87:3336-3343

13. Shih SC, Ju M, Liu N, Smith LE: Selective stimulation of VEGFR-1 prevents oxygen-induced retinal vascular degeneration in retinopathy of prematurity. J Clin Invest 2003, 112:50-57

14. Fong GH, Rossant J, Gertsenstein M, Breitman ML: Role of the Flt-1 receptor tyrosine kinase in regulating the assembly of vascular endothelium. Nature 1995, 376:66-70

15. Kiba A, Sagara H, Hara T, Shibuya M: VEGFR-2-specific ligand VEGF-E induces non-edematous hyper-vascularization in mice. Biochem Biophys Res Commun 2003, 301:371-377

16. Li B, Ogasawara AK, Yang R, Wei W, He GW, Zioncheck TF, Bunting S, de Vos AM, Jin H: KDR (VEGF receptor 2) is the major mediator for the hypotensive effect of VEGF. Hypertension 2002, 39:1095-1100

17. Cooper ME, Vranes D, Youssef S, Stacker SA, Cox AJ, Rizkalla B, Casley DJ, Bach LA, Kelly DJ, Gilbert RE: Increased renal expression of vascular endothelial growth factor (VEGF) and its receptor VEGFR-2 in experimental diabetes. Diabetes 1999, 48:2229-2239

18. Nakagawa T: Uncoupling of the VEGF-endothelial nitric oxide axis in diabetic nephropathy: an explanation for the paradoxical effects of VEGF in renal disease. Am J Physiol Renal Physiol 2007, 292:F1665F1672

19. Nakagawa T, Kosugi T, Haneda M, Rivard CJ, Long DA: Abnormal angiogenesis in diabetic nephropathy. Diabetes 2009, 58:1471-1478

20. Li B, Fuh G, Meng G, Xin X, Gerritsen ME, Cunningham B, de Vos AM: Receptor-selective variants of human vascular endothelial growth factor. Generation and characterization, J Biol Chem 2000, 275: 29823-29828

21. Gerber HP, McMurtrey A, Kowalski J, Yan M, Keyt BA, Dixit V, Ferrara $\mathrm{N}$ : Vascular endothelial growth factor regulates endothelial cell survival through the phosphatidylinositol 3'-kinase/Akt signal transduction pathway. Requirement for Flk-1/KDR activation. J Biol Chem 1998, 273:30336-30343

22. Gille H, Kowalski J, Li B, LeCouter J, Moffat B, Zioncheck TF, Pelletier $N$, Ferrara N: Analysis of biological effects and signaling properties of FIt-1 (VEGFR-1) and KDR (VEGFR-2). A reassessment using novel receptor-specific vascular endothelial growth factor mutants. J Biol Chem 2001, 276:3222-3230

23. Mu W, Long DA, Ouyang X, Agarwal A, Cruz PE, Roncal CA, Nakagawa T, Yu X, Hauswirth WW, Johnson RJ: Angiostatin overexpres- sion is associated with an improvement in chronic kidney injury by an anti-inflammatory mechanism. Am J Physiol Renal Physiol 2009, 296:F145-F152

24. Nakagawa T, Sato W, Glushakova O, Heinig M, Clarke T, CampbellThompson M, Yuzawa Y, Atkinson M, Johnson RJ, Croker B: Diabetic eNOS knockout mice develop advanced diabetic nephropathy. J Am Soc Nephrol 2007, 18:539-550

25. Masaki T, Chow F, Nikolic-Paterson DJ, Atkins RC, Tesch GH: Heterogeneity of antigen expression explains controversy over glomerular macrophage accumulation in mouse glomerulonephritis. Nephrol Dial Transplant 2003, 18:178-181

26. Yuzawa Y, Brentjens JR, Brett J, Caldwell PR, Esposito C, Fukatsu A Godman G, Stern D, Andres G: Antibody-mediated redistribution and shedding of endothelial antigens in the rabbit. J Immunol 1993, 150:5633-5646

27. Working Group of the International IgA Nephropathy Network and the Renal Pathology Society, Roberts IS, Cook HT, Troyanov S, Alpers CE, Amore A, Barratt J, et al: The Oxford classification of IgA nephropathy: pathology definitions, correlations, and reproducibility. Kidney Int 2009, 76:546-556

28. Nakayama T, Sato W, Yoshimura A, Zhang L, Kosugi T, CampbellThompson M, Kojima H, Croker BP, Nakagawa T: Endothelial von Willebrand factor release due to eNOS deficiency predisposes to thrombotic microangiopathy in mouse aging kidney. Am J Pathol 2010, 176:2198-2208

29. Wu LW, Mayo LD, Dunbar JD, Kessler KM, Baerwald MR, Jaffe EA, Wang D, Warren RS, Donner DB: Utilization of distinct signaling pathways by receptors for vascular endothelial cell growth factor and other mitogens in the induction of endothelial cell proliferation. J Biol Chem 2000, 275:5096-5103

30. Flyvbjerg A, Schrijvers BF, De Vriese AS, Tilton RG, Rasch R: Compensatory glomerular growth after unilateral nephrectomy is VEGF dependent. Am J Physiol Endocrinol Metab 2002, 283:E362-E366

31. Senthil D, Choudhury GG, McLaurin C, Kasinath BS: Vascular endothelial growth factor induces protein synthesis in renal epithelial cells: a potential role in diabetic nephropathy. Kidney Int 2003, 64:468-479

32. Facemire CS, Nixon AB, Griffiths R, Hurwitz H, Coffman TM: Vascular endothelial growth factor receptor 2 controls blood pressure by regulating nitric oxide synthase expression. Hypertension 2009 , 54:652-658

33. Iatropoulos MJ, Williams GM: Proliferation markers. Exp Toxicol Pathol 1996, 48:175-181

34. Ohashi R, Shimizu A, Masuda $Y$, Kitamura H, Ishizaki M, Sugisaki $Y$, Yamanaka N: Peritubular capillary regression during the progression of experimental obstructive nephropathy. J Am Soc Nephrol 2002, 13:1795-1805

35. Floege J, Eitner F, Alpers CE: A new look at platelet-derived growth factor in renal disease. J Am Soc Nephrol 2008, 19:12-23

36. Eremina V, Cui S, Gerber H, Ferrara N, Haigh J, Nagy A, Ema M, Rossant J, Jothy S, Miner JH, Quaggin SE: Vascular endothelial growth factor a signaling in the podocyte-endothelial compartment is required for mesangial cell migration and survival. J Am Soc Nephrol 2006, 17:724-735

37. Thomas S, Vanuystel J, Gruden G, Rodriguez V, Burt D, Gnudi L, Hartley B, Viberti G: Vascular endothelial growth factor receptors in human mesangium in vitro and in glomerular disease. J Am Soc Nephrol 2000, 11:1236-1243

38. Pettersson A, Nagy JA, Brown LF, Sundberg C, Morgan E, Jungles S, Carter R, Krieger JE, Manseau EJ, Harvey VS, Eckelhoefer IA, Feng D, Dvorak AM, Mulligan RC, Dvorak HF: Heterogeneity of the angiogenic response induced in different normal adult tissues by vascular permeability factor/vascular endothelial growth factor. Lab Invest 2000, 80:99-115

39. Kremer C, Breier G, Risau W, Plate KH: Up-regulation of flk-1/vascular endothelial growth factor receptor 2 by its ligand in a cerebral slice culture system. Cancer Res 1997, 57:3852-3859

40. Hudkins KL, Gilbertson DG, Carling M, Taneda S, Hughes SD, Holdren MS, Palmer TE, Topouzis S, Haran AC, Feldhaus AL, Alpers CE: Exogenous PDGF-D is a potent mesangial cell mitogen and causes a severe mesangial proliferative glomerulopathy. J Am Soc Nephrol 2004, 15:286-298

41. Hakroush S, Moeller MJ, Theilig F, Kaissling B, Sijmonsma TP, Jugold M, Akeson AL, Traykova-Brauch M, Hosser H, Hähnel B, Gröne HJ, Koesters R, Kriz W: Effects of increased renal tubular vascular endo- 
thelial growth factor (VEGF) on fibrosis, cyst formation, and glomerular disease. Am J Pathol 2009, 175:1883-1895

42. Ball SG, Shuttleworth CA, Kielty CM: Vascular endothelial growth factor can signal through platelet-derived growth factor receptors. J Cell Biol 2007, 177:489-500

43. Veron D, Reidy KJ, Bertuccio C, Teichman J, Villegas G, Jimenez J, Shen W, Kopp JB, Thomas DB, Tufro A: Overexpression of VEGF-A in podocytes of adult mice causes glomerular disease. Kidney Int 2010, 77:989-999

44. Sison K, Eremina V, Baelde H, Min W, Hirashima M, Fantus IG, Quaggin SE: Glomerular structure and function require paracrine, not autocrine, VEGF-VEGFR-2 signaling. J Am Soc Nephrol 2010, 21: $1691-1701$

45. Vitalone MJ, O'Connell PJ, Jimenez-Vera E, Yuksel A, Wavamunno M, Fung CL, Chapman JR, Nankivell BJ: Epithelial-to-mesenchymal transition in early transplant tubulointerstitial damage. J Am Soc Nephrol 2008, 19:1571-1583

46. Mann JF, Schmieder RE, McQueen M, Dyal L, Schumacher H, Pogue J, Wang X, Maggioni A, Budaj A, Chaithiraphan S, Dickstein K, Keltai M, Metsarinne K, Oto A, Parkhomenko A, Piegas LS, Svendsen TL, Teo KK, Yusuf S; ONTARGET investigators: Renal outcomes with telmisartan, ramipril, or both, in people at high vascular risk (the ONTARGET study): a multicentre, randomised, double-blind, controlled trial. Lancet 2008, 372:547-553

47. Brandes RP, Schmitz-Winnenthal FH, Félétou M, Gödecke A, Huang PL, Vanhoutte PM, Fleming I, Busse R: An endothelium-derived hy- perpolarizing factor distinct from $\mathrm{NO}$ and prostacyclin is a major endothelium-dependent vasodilator in resistance vessels of wild-type and endothelial NO synthase knockout mice. Proc Natl Acad Sci USA 2000, 97:9747-9752

48. Iwakiri Y, Cadelina G, Sessa WC, Groszmann RJ: Mice with targeted deletion of eNOS develop hyperdynamic circulation associated with portal hypertension. Am J Physiol Gastrointest Liver Physiol 2002, 283:G1074-G1081

49. Yang S, Wei S, Pozzi A, Capdevila JH: The arachidonic acid epoxygenase is a component of the signaling mechanisms responsible for VEGF-stimulated angiogenesis. Arch Biochem Biophys 2009, 489: 82-91

50. Webler AC, Michaelis UR, Popp R, Barbosa-Sicard E, Murugan A, Falck JR, Fisslthaler B, Fleming I: Epoxyeicosatrienoic acids are part of the VEGF-activated signaling cascade leading to angiogenesis. Am J Physiol Cell Physiol 2008, 295:C1292-C1301

51. Nishimura S, Manabe I, Nagasaki M, Hosoya Y, Yamashita H, Fujita H, Ohsugi M, Tobe K, Kadowaki T, Nagai R, Sugiura S: Adipogenesis in obesity requires close interplay between differentiating adipocytes, stromal cells, and blood vessels. Diabetes 2007, 56:1517-1526

52. Tam J, Duda DG, Perentes JY, Quadri RS, Fukumura D, Jain RK: Blockade of VEGFR2 and not VEGFR1 can limit diet-induced fat tissue expansion: role of local versus bone marrow-derived endothelial cells. PLoS One 2009, 4:e4974

53. Pruna A, Peyri N, Berard M, Boffa MC: Thrombomodulin is synthesized by human mesangial cells. Kidney Int 1997, 51:687-693 